\title{
Hubungan Pemanfaatan Media Internet Dengan Sikap Siswa Terhadap Kemampuan dalam Antisipasi Tindak KSA (Kekerasan Seksual Anak) di Pengajian Anak-anak Al-Falaah Blunyahgede Yogyakarta
}

\author{
Indriana Widya Puspitasari ${ }^{1}$, Diah Wulandari ${ }^{2}$, Fitra Duhida ${ }^{3}$ \\ Kebidanan Sekolah Vokasi Universitas Gadjah Mada ${ }^{1,2,3}$ \\ Indriana.widya.p@gmail.com¹, diah_wulandari@ugm.ac.id2, fitra.duhita@ugm.ac.id ${ }^{3}$
}

\begin{abstract}
ABSTRAK
Latar Belakang: Anak dan remaja merupakan masa pencarian jati diri. Internet berperan besar bagi kehidupan mereka sehingga paparan pornografi mudah diterima. Oleh sebab itu, internet menjadi salah satu penyebab KSA (Kekerasan Seksual Anak).

Tujuan: Penelitian ini bertujuan untuk mengetahui hubungan pemanfaatan media internet dengan sikap siswa terhadap kemampuan dalam antisipasi tindak KSA.

Metode: Penelitian ini merupakan studi analitik cross sectional. Populasi target yaitu siswa usia 10-14 tahun, sedangkan populasi terjangkau yaitu seluruh siswa kelas TA PAA Al-Falaah Blunyahgede Yogyakarta. Pengambilan sampel menggunakan Total Sampling sebanyak 34 anak. Penelitian dilakukan pada 8-13 September menggunakan instrumen yang telah diuji validitas dan reliabilitasnya. Analisis data menggunkan uji Spearman ra $n k(=5 \%)$.

Hasil: Hasil penelitian menunjukkan bahwa dari 34 siswa PAA AL-Falaah 19 anak 55,88\% memanfaatkan media internet tinggi dan 20 anak 58,82\% memiliki sikap positif terhadap kemampuan dalam antisipasi tindak KSA. Uji korelasi Spearman Rank menujukkan p value 0,047 < 0,05 dan nilai $\rho$ sebesar 0,344. Artinya ada hubungan pemanfaatan media internet dengan sikap siswa terhadap kemampuan dalam antisipasi tindak KSA dengan kekuatan lemah

Kesimpulan: Pemanfaatan media internet berhubungan dengan sikap anak terhadap kemampuan dalam antisispasi tindak KSA namun internet juga memiliki dampak positif bagi penggunanya.

Kata kunci: pemanfaatan internet, sikap, KSA
\end{abstract}

\section{ABSTRACT}

Background: Child and adolescent is a period to finding ego. Internet plays a major role in their lives to accepted pornography easily. Therefore, the Internet is one of the reasons of CSA (Child Sexual Abuse)

Objective: This study aims to know the relationship among the use of internet media and the students' attitudes toward capabilities in anticipation of the CSA action.

Methods: This study was a cross sectional analytical study. Target population were students aged ten to fourteen, while the affordable population were the entire graders at TA PAA Al-Falaah Blunyahgede Yogyakarta. The sampling was used total sampling as many as 34 children. The study was conducted on September, $8^{\text {th }}$ to $13^{\text {th }}$ using an instrument that has been tested for validity and reliability. Data analyzed used the Spearman rank test ( $=5 \%$ ).

Result: The rsultsThe results showed that of the 34 students PAA AL-Falaah, 19 children (55.88\%) utilizing high internet media and 20 children (58.82\%) have a positive attitude towards capability in anticipation of the CSA action. The spearman rank correlation test showed p value of $0.047<0.05$ and $\rho$ value of 0.344. It means that there was a relationship between the use of Internet media and the students' attitudes toward capabilities in anticipation of the CSA action with the weak force.

Conclusion: The use of the internet media is associated with the child's attitude towards the ability to CSA action anticipation but the Internet media also have a positive impact on users.

Keywords: internet use, attitudes, CSA 


\section{PENDAHULUAN}

Internet menjadi salah satu bagian dari kehidupan masyarakat. Bagi sebagian orang, internet merupakan suatu kebutuhan pokok yang tidak bisa ditinggalkan.

Berdasarkan penelitian Rahayu (2014), terdapat gambaran bahwa usia anak-anak pengguna internet di beberapa warnet (warung internet) adalah usia anak sekolah yaitu sekitar 6-15 tahun. Anakanak memanfaatkan facebook untuk chatting, saling mengomentari status teman, melihat profil teman, ada juga beberapa anak sudah mulai mencari pasangan lewat Facebook, dan selebihnya Facebook dimanfaatkan untuk bermain game. Selain Facebook, situs atau konten yang sering dikunjungi anak-anak adalah Google dan Youtube

Lisa (2013) pada dasarnya masa remaja adalah masa penemuan jati diri, peningkatan kemandirian sosial, dan transformasi menjadi individu yang unik. Sementara rekan-rekan, orang tua, dan pendidik memiliki dampak langsung pada interaksi tatap muka remaja sehari-hari, internet memainkan peran yang semakin besar setiap tahapan hidup menurut.

Sementara itu, informasi atau penjelasan sehubungan dengan perubahan- perubahan fisik yang dialami remaja terlebih lagi mengenai seks, seringkali kurang mendapat tanggapan yang positif atau memuaskan dari lingkungan, terutama orang tua dan keluarga. Tidak tersedianya informasi yang akurat dan "benar" tentang kesehatan reproduksi memaksa remaja berusaha mencari akses dan melakukan eksplorasi sendiri menurut BPPM (2011).

Berdasarkan penelitian Mitchell, Finkelhor dan Wolak (2005) menyampaikan bahwa $13 \%$ dari populasi studi menerima pelecehan seksual melaului internet. $4 \%$ dari mereka menerima permintaan online untuk mengirimkan gambar seksual. Selain itu Beech, menyampaikan bahwa ada banyak hal yang bisa dilakukan melalui Internet dan mudah diakses oleh anak-anak, yaitu pesan, gambar dan video pornografi, komunikasi berbau seksual dengan pengguna internet lainnya, game berbau seksual, dan lain sebagainya. Dalam hal ini internet merupakan salah satu penyebab terjadinya KSA (Kekerasan Seksual Anak).

Data dari Komnas PA (Komisi Nasional Perlindungan Anak) periode I di tahun 2013 atau mulai Januari sampai akhir Juni 2013 terdapat 1032 kasus kekerasan anak yang terjadi di Indonesia. Berdasarkan jumlah tersebut kekerasan fisik tercatat ada 294 kasus atau 28 persen, kekerasan psikis 203 kasus atau 20 persen dan kekerasan seksual 535 kasus atau 52\%.

Berdasarkan fenomena tersebut, penulis bermaksud mengadakan penelitian tentang hubungan pemanfaatan media internet dengan sikap siswa terhadap kemampuan dalam antisipasi tindak kekerasan seksual anak di PAA AlFalaah Blunyahgede Yogyakarta dengan pertimbangan siswa kelas TA (kelas 5-6 SD) usia 10-13 tahun merupakan masa pra remaja dan remaja awal dimana pada usia tersebut sudah mengalami pubertas.

Penulis mengambil lokasi di PAA Al-Falaah, Blunyahgede Yogyakarta karena merupakan salah satu lembaga pendidikian informal di tengah kota Sleman dimana kabupaten Sleman memiliki tingkat KSA yang tinggi dengan banyaknya imigran dan pengaruh kemajuan media, sehingga sangat memungkinkan para siswa memperoleh kemudahan dalam mengakses berbagai informasi termasuk seksualitas.

Rumusan masalah dalam penelitian ini adalah adakah hubungan pemanfaatan media internet dengan sikap siswa terhadap kemampuan dalam antisipasi tindak kekerasan seksual anak. Adapun tujuan umum penelitian ini adalah untuk mengetahui hubungan antara pemanfaatan media internet dengan sikap siswa kelas TA PAA AlFalaah Yogyakarta terhadap tindak kekerasan seksual anak.

Manfaat penelitian ini yaitu sebagai rujukan untuk mengidentifikasi penyebab kejadian kekerasan seksual anak sehingga dapat mengantisipasi kejadian tersebut.

Ada beberapa indikator yang akan dipergunakan untuk mengetahui dalam pemanfaatan media internet oleh anak- 
anak. Penentuan indikator ini merujuk berdasarkan temuan dari penelitian sebelumnya yang berkaitan dengan pemanfaatan media internet oleh anak. Berdasarkan Penelitian tentang Penggunaan internet oleh anak di Klaten oleh Rahayu (2014) mendapati banyak temuan (a) anak ketika online, apa yang dilakukan anak ketika online. (b) konsekuensi positif dan negatif bagi anak. (c) kemampuan sosial digital, interaksi sosial dan bermain. (d) pemanfaatan fasilitas internet. (e) Intensitas akses yang berupa gambaran dan berapa sering informan menggunakan internet. (f) sikap keluarga terhadap anak. Dari hasil temuan penelitian tersebut, untuk mengarahkan penelitian dan memberikan batasan dalam pemanfaatan media internet penelitian ini mengambil dari beberapa temuan penelitian sebelumnya.

Menurut Azwar (2013), sikap merupakan suatu bentuk evaluasi atau merupakan suatu reaksi perasaan seseorang yang bisa merupakan perasaan mendukung atau memihak terhadap suatu objek atau bahkan tidak mendukung atau memihak terhadap suatu objek tertentu sebagai responyang timbul yang bisa berupa pernyataan afeksi, keyakinan, serta pernyataan lisan.

Ada tidak komponen sikap yaitu 1) Komponen Kognitif. Komponen ini berisi kepercayaan seseorang mengenai apa yang berlaku atau apa yang benar bagi obyek sikap. 2) Komponen Afektif. Komponen ini merupakan kecenderungan dalam berperilaku berkaitan dengan obyek sikap yang dihadapi seseorang. 2) Komponen Perilaku. Komponen ini merupakan kecenderungan dalam berperilaku berkaitan dengan obyek sikap yang dihadapi seseorang.

$$
\text { Menurut Undang- Undang }
$$

Perlindungan Anak RI 23 tahun 2002 KSA adalah segala bentuk tindakan seksual yang dilakukan dengan anak dibawah 18 tahun tergolong sebagai kekerasan seksual. Baik tindakan seksual tersebut disertai perlawanan atau tidak, ancaman atau tidak, paksaan atau tidak, tetap digolongkan sebagai kekerasan seksual.
Berdasarkan uraian tinjauan teori, maka dapat disusun skema kerangka teori sebagai berikut:

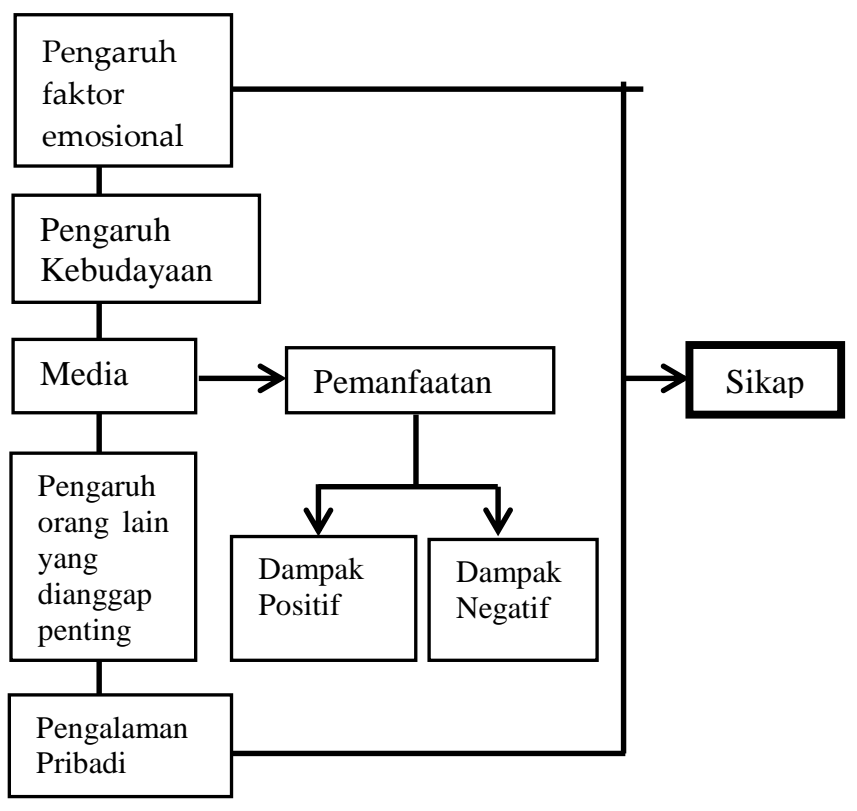

Gambar 1 kerangka teori

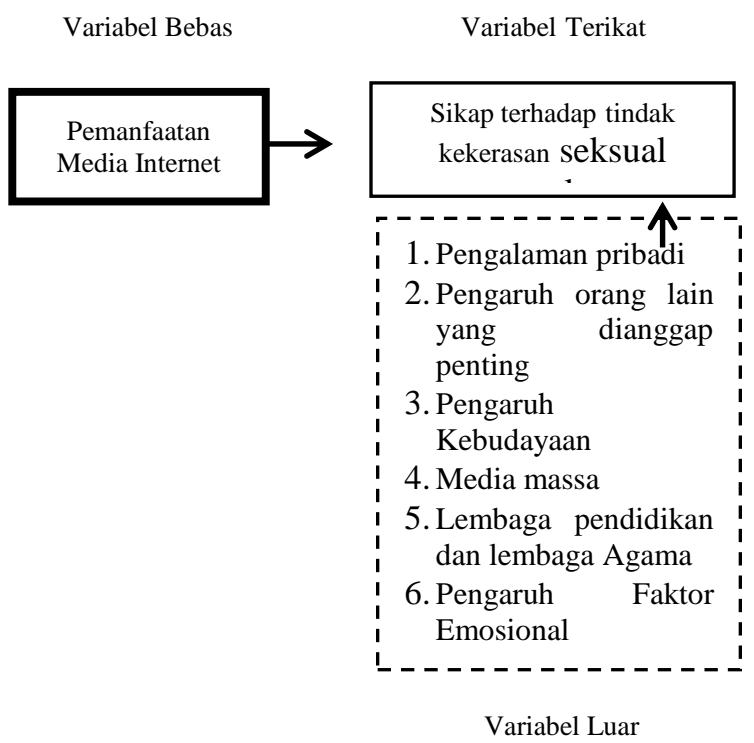

Gambar 2 Kerangka Konsep

Hipotesis Penelitian Ini Adalah "Ada Hubungan Pemanfaatan Media Internet Dengan Sikap Siswa Terhadap Kemampuan Dalam Antisipasi Tindak Kekerasan Seksual Anak"

\section{METODE}

Desain penelitian ini adalah studi analitik cross sectional, yaitu peneliti mengambil data di PAA Al-Falaah dengan observasi langsung menggunakan 
kuesioner dalam satu kali waktu tanpa di follow up.

Penelitian dilakukan di PAA Al-

Falaah Blunyahgede Yogyakarta pada bulan September 2015. Populasi target pada penelitian ini adalah seluruh siswa usia 10 - 14 tahun sebagai masa pra remaja dan remaja awal yang sudah mengalami pubertas. Sehingga populasi terjangkaunya adalah seluruh siswa kelas Ta (usia 10 - 14 tahun) PAA Al-falaah Blunyahgede Yogyakarta.

Besaran sampel di hitung dengan menggunakan rumus slovin sebagai berikut

: $\mathrm{N}=\frac{N}{1+\left(N \times e^{2}\right)}$ dengan hasil sampel sebanyak 36 anak.

Tabel.1 Definisi Operasional

\begin{tabular}{|c|c|c|c|c|}
\hline Variabel & $\begin{array}{l}\text { Definisi } \\
\text { Operasional }\end{array}$ & $\begin{array}{l}\text { Alat } \\
\text { Ukur }\end{array}$ & $\begin{array}{l}\text { Hasil } \\
\text { Ukur }\end{array}$ & Skala \\
\hline $\begin{array}{l}\text { Variabel } \\
\text { bebas: } \\
\text { Pemanf } \\
\text { aatan } \\
\text { media } \\
\text { internet }\end{array}$ & $\begin{array}{l}\text { Skor nilai } \\
\text { kuesioner } \\
\text { pemanfaatan } \\
\text { internet } \\
\text { mengenai } \\
\text { suatu proses, } \\
\text { cara atau } \\
\text { perbuatan } \\
\text { dalam } \\
\text { menggunakan } \\
\text { internet agar } \\
\text { memiliki } \\
\text { faedah bagi } \\
\text { penggunanya. }\end{array}$ & $\begin{array}{l}\text { Kues } \\
\text { ioner }\end{array}$ & $\begin{array}{l}\text { Total } \\
\text { skor } \\
\text { jawaban } \\
\text { benar } 0 \\
-27 \\
\text { soal. }\end{array}$ & Rasio \\
\hline $\begin{array}{l}\text { Variabel } \\
\text { terikat: }\end{array}$ & $\begin{array}{l}\text { Skor nilai } \\
\text { kuesioner } \\
\text { tentang respon }\end{array}$ & $\begin{array}{l}\text { Kues } \\
\text { ioner }\end{array}$ & $\begin{array}{l}\text { Total skor } \\
\text { jawaban } \\
\text { benar } 0 \text { - }\end{array}$ & Rasio \\
\hline $\begin{array}{l}\text { Sikap } \\
\text { siswa } \\
\text { terhada }\end{array}$ & $\begin{array}{l}\text { yang biasanya } \\
\text { memberikan } \\
\text { penilaian }\end{array}$ & & 20 soal. & \\
\hline $\begin{array}{l}\mathrm{p} \\
\text { kemam } \\
\text { puan } \\
\text { dalam } \\
\text { antisipa }\end{array}$ & $\begin{array}{l}\text { menerima atau } \\
\text { menolak } \\
\text { terhadap } \\
\text { objek dalam } \\
\text { memperhitung }\end{array}$ & & & \\
\hline $\begin{array}{l}\text { si tindak } \\
\text { kekeras } \\
\text { an } \\
\text { seksual } \\
\text { anak }\end{array}$ & $\begin{array}{l}\text { kan hal-hal } \\
\text { yang akan } \\
\text { (belum) terjadi } \\
\text { tentang KSA. }\end{array}$ & & & \\
\hline
\end{tabular}

Data yang digunakan adalah data primer dengan memberikan kuesioner. Adapun kisikisi kuesioner adalah sebagai berikut:

Tabel 2. Kisi-kisi Kuesioner Pemanfaatan Internet

\begin{tabular}{|c|c|c|c|c|c|}
\hline \multirow[b]{2}{*}{ No } & \multirow[b]{2}{*}{ Indikator } & \multicolumn{2}{|c|}{ Jumlah Soal } & \multicolumn{2}{|c|}{ No soal } \\
\hline & & $\begin{array}{c}\text { Favour } \\
\text { able }\end{array}$ & $\begin{array}{l}\text { Unfavo } \\
\text { urable }\end{array}$ & $\begin{array}{c}\text { Favour } \\
\text { able }\end{array}$ & $\begin{array}{l}\text { Unfavo } \\
\text { urable }\end{array}$ \\
\hline & Kemampua & & & & \\
\hline 1 & $\begin{array}{l}\text { n sosial } \\
\text { digital, } \\
\text { interaksi } \\
\text { dan } \\
\text { bermain }\end{array}$ & 8 & 2 & $\begin{array}{c}4,5,7, \\
8,9 \\
10,11 \\
12\end{array}$ & 3,6 \\
\hline 2 & $\begin{array}{l}\text { Konsekuen } \\
\text { si positif } \\
\text { dan } \\
\text { negative }\end{array}$ & 8 & & $\begin{array}{l}13,14 \\
15,16 \\
17,18\end{array}$ & \\
\hline 3 & $\begin{array}{l}\text { Pemanfaata } \\
\mathrm{n} \text { fasilitas } \\
\text { internet }\end{array}$ & 6 & & $\begin{array}{l}19,20 \\
21,22\end{array}$ & \\
\hline 4 & $\begin{array}{l}\text { Intensitas } \\
\text { akses }\end{array}$ & 5 & & 1,2 & \\
\hline 5 & $\begin{array}{l}\text { Dukungan } \\
\text { keluarga } \\
\text { terhadap } \\
\text { anak }\end{array}$ & 6 & 1 & $\begin{array}{l}23,24 \\
26,27\end{array}$ & 25 \\
\hline
\end{tabular}

Tabel. 3. Kisi-kisi Kuesioner Sikap terhadap Antisipasi Tindak KSA

\begin{tabular}{|c|c|c|c|c|c|}
\hline \multirow[t]{2}{*}{ No } & \multirow{2}{*}{$\begin{array}{c}\text { Indika } \\
\text { tor }\end{array}$} & \multirow{2}{*}{$\begin{array}{c}\text { Komponen } \\
\text { Sikap }\end{array}$} & \multicolumn{2}{|c|}{ No Soal } & \multirow{2}{*}{$\sum_{\text {soal }}$} \\
\hline & & & $\begin{array}{l}\text { Favou } \\
\text { rable }\end{array}$ & $\begin{array}{c}\text { Unfavo } \\
\text { urable }\end{array}$ & \\
\hline 1 & Defini & Kognitif & 1 & & \\
\hline & si KSA & $\begin{array}{l}\text { Afektif } \\
\text { Konatif }\end{array}$ & 7 & & 2 \\
\hline 2 & Faktor & Kognitif & & & \\
\hline & $\begin{array}{c}\text { risisko } \\
\text { KSA }\end{array}$ & $\begin{array}{l}\text { Afektif } \\
\text { Konatif }\end{array}$ & $2,3,5$ & 4 & 4 \\
\hline 3 & $\begin{array}{c}\text { Damp } \\
\text { ak } \\
\text { KSA }\end{array}$ & $\begin{array}{c}\text { Kognitif } \\
\text { Afektif } \\
\text { Konatif }\end{array}$ & $\begin{array}{c}6,8 \\
10\end{array}$ & 9 & 4 \\
\hline 4 & $\begin{array}{c}\text { Pelaku } \\
\text { KSA }\end{array}$ & $\begin{array}{l}\text { Kognitif } \\
\text { Afektif } \\
\text { Konatif }\end{array}$ & $\begin{array}{c}11,12, \\
13\end{array}$ & & 4 \\
\hline 5 & $\begin{array}{l}\text { Jenis- } \\
\text { jenis } \\
\text { KSA }\end{array}$ & $\begin{array}{c}\text { Kognitif } \\
\text { Afektif } \\
\text { Konatif }\end{array}$ & $\begin{array}{l}16,20 \\
14,18 \\
19\end{array}$ & 15,17 & 6 \\
\hline
\end{tabular}

Uji validitas pada kuesioner pemanfaatan internet dilakukan pada tanggal 5 September 2015 pada siswa kelas 5 SD sebanyak 30 anak di SD N 1 Petinggen, Yogyakarta. Pada kuesioner ini terdapat 37 soal yang di uji validitasnya dan didapatkan hasil 27 soal valid. Dari hasil pngujian ini, 10 soal yang tidak valid di hapus oleh peneliti. 27 soal yang valid 
ini sudah mewakili setiap indikator. Pada kuesioner sikap siswa terhadap kemampuan dalam antisipasi tindak KSA terdapat 27 soal yang diuji validitasnya, hasilnya 20 soal valid dan 7 soal tidak valid. 7 soal yang tidak valid dihapus oleh peneliti. 20 soal valid sudah mewakili setiap indikator soal pada kisi-kisi.

Pada pengujian reliabilitas pada kuesioner pemanfaatan media internet didapatkan hasil spearman brown equel length 0,914 dan unequal length 0,915 yang berarti $>0,7$ sehingga kuesioner dinyatakan reliabel.

Pengujian reliabilitas pada instrument sikap terhadap tindak KSA dilakukan dengan menggunakan Koefisien Realibilitas cronbach's Alpha. Hasil perhitungan reliabiltas kuesioner sikap siswa terhadap kemampuan dalam antisispasi tindak KSA sebanyak 0,875 yang berarti hasilnya $>0,7$, maka kuesioner dikatakan reliabel.

Analisis univariabel dilakukan melalui distribusi frekuensi. Pada kuesioner pemanfaatan media internet, nilai rentang dibagi menjadi kategori sangat tinggi jika rata- rata skor 21,6 - 27, tinggi jika ratarata skor 16,2 - 21,6, cukup jika rata-rata skor10,8 - 16,2, kurang tinggi jika rata-rata skor 5,4-10,8, rendah jika rata-rata skor 05,4 .

Sedangkan pada kuesioner sikap terhadap kemampuan dalam antisipasi tindak KSA, skor mentah di buat menjadi skor baku atau di hitung $\mathrm{T}$ skornya dengan rumus:

$$
\text { T skor }=50+10 \cdot \frac{(x 1-x)}{2 d}
$$

Tabel. 4 Intrepertasi nilai koefisien korelasi

\begin{tabular}{ll}
\hline $0,00-0,20$ & Sangat lemah \\
$0,21-0,40$ & Lemah \\
$0,41-0,70$ & Sedang \\
$0,71-0,90$ & Kuat \\
$0,91-0,99$ & Sangat kuat \\
1,00 & Sempurna \\
\hline
\end{tabular}

\section{HASIL DAN PEMBAHASAN}

\section{A. HASIL}

\section{Gambaran Lokasi Penelitian}

PAA Al-Falaah (Pengajian AnakAnak Masjid Al-Falaah) merupakan suatu lembaga pengajian anak-anak yang terdiri dari anak-anak pra sekolah sampai kelas 6 Sekolah Dasar. Lembaga pengajian ini terletak ditengah kota yang memungkinkan anak-anaknya mudah dan sering dalam mengakses internet. Lembaga pengajian ini terdiri dari 120 anak dan dibagi menjadi 3 kelas. Kelas Alif terdiri dari anak-anak prasekolah sampai kelas 2 SD. Kelas Ba terdiri dari anak-anak kelas 3 sampai 4 sd. Kelas Ta terdiri dari anak-anak kelas 5-6 SD Peneliti mengambil responden kelas Ta usia 10-13 tahun sebanyak 34 anak. Soetjiningsih, SpAK. (2012) anak usia ini cenderung memiliki karakteristik psikologis yang sama dan merupakan masa remaja awal sehingga pemahaman tentang kesehatan reproduksinya cenderung sama.

\section{Karakteristik Subyek Penelitian}

a. Karakteristik Umum

Tabel. 5 Distribusi frekuensi karakteristik responden di PAA Al Falaah

\begin{tabular}{lcc}
\hline Karakteristik & Frekuensi & $\begin{array}{c}\text { Prosentase } \\
(\%)\end{array}$ \\
\hline Usia & & \\
10 tahun & 6 & 17,64 \\
11 tahun & 18 & 53,94 \\
12 tahun & 7 & 20,58 \\
13 tahun & 3 & 8,82 \\
Jenis kelamin & & \\
Laki - laki & 14 & 41,176 \\
Perempuan & 20 & 58,82 \\
Pendidikan terakhir Ayah & \\
SD & 0 & \\
SMP & 4 & 11,76 \\
SMA & 13 & 38,23 \\
S1 & 17 & 50 \\
S2 & 1 & 2,94 \\
Pendidikan terakhir Ibu & \\
SD & 1 & \\
SMP & 6 & 2,94 \\
SMA & 15 & 17,64 \\
S1 & 12 & 44,11 \\
S2 & 0 & 35,29 \\
\hline
\end{tabular}

Sumber: data primer, 2015
Karakteristik umum subyek penelitian menunjukkan bahwa dari 34 anak siswa kelas TA PAA Al Falaah Blunyahgede, paling banyak adalah anak usia 11 tahun sebanyak 18 anak (53,94\%), yang kedua adalah anak usia 12 tahun sebanyak 7 anak (20,58\%), yang ketiga anak usia 10 tahun sebanyak 6 anak $(17,64 \%)$, dan terakhir anak usia 13 tahun sebanyak 3 anak $(8,82 \%)$. Usia responden tersebut sudah memenuhi kriteria inklusi. 
Berdasarkan tabel 5 dari 34 anak siswa kelas TA PAA Al Falaah Blunyahgede di dominasi oleh siswa dengan jenis kelamin perempuan yaitu sebanyak 20 anak (58,82\%), kemudian siswa berjenis kelamin laki-laki sebanyak 14 anak (41,176\%). Semua siswa tersebut pernah mengakses internet.

Berdasarkan tabel 5 dapat dilihat bahwa pendidikan terakhir ayah kebanyakan berasal dari menengah keatas yaitu dari SMP sebanyak 4 orang $(11,76 \%)$, SMA 13 orang $(32,23)$, S1 sebanyak 17 orang $(50 \%)$, dan S2 1 orang $(2,94 \%)$. Selain itu pendidikan terakhir Ibu pun demikian, didominasi dari pendidikan menengah keatas. Pendidikan terakhir SD hanya 1 orang $(2,94 \%)$, selebihnya dari menengah keatas yaitu SMP sebanyak 6 orang $(17,64 \%)$, SMA sebanyak 15 orang $(44,11 \%)$, dan S1 sebanyak 12 orang $(35,29 \%)$. Artinya, rata-rata pendidikan terakhir orang tua responden cukup tinggi yang berpengaruh dalam pemberian fasilitas internet pada anak.

b. Deskripsi Pemanfaatan Media Internet

Tabel. 6 Pemanfaatan media internet oleh siswa di PAA AL Falaah Blunyahgede Yogyakarta

\begin{tabular}{ccccccc}
\hline Variabel & Skor & $\sum^{2}$ & Mean & Med & Min & Max \\
& & $(\%) \mathbf{n}=34$ & & & & \\
\hline Pemanfaat & median & $19(55,8)$ & 20,02 & 20 & 12 & 25 \\
an Media & $<$ median & $15(44,2)$ & & & & \\
Internet & & & & & & \\
\end{tabular}

\section{Sumber: data primer, 2015}

Berdasarkan tabel 6 dapat dilihat bahwa skor minimum dari 34 anak sebanyak 12 dan maximum sebanyak 25 , rata-rata skor pemanfaatan media internet sebanyak 20,02 dengan median 20. Total skor jawaban benar sebanyak 27. Total anak yang memiliki nilai median sebanyak 19 anak 55,88\% sedangkan < median 15 anak $44,11 \%$. Artinya pemanfaatan media internet oleh anak-anak PAA Al-falaah tinggi.

c. Sikap siswa terhadap kemampuan dalam antisipasi tindak KSA
Tabel. 7 Sikap siswa terhadap kemampuan dalam antisipasi tindak KSA (T skor)

\begin{tabular}{|c|c|c|c|c|c|c|}
\hline Variabel & Skor & $\sum_{\substack{(\%) \\
n=34}}$ & Mean & Med & Min & Max \\
\hline $\begin{array}{l}\text { Sikap siswa } \\
\text { terhadap } \\
\text { Kemampuan } \\
\text { dalam } \\
\text { antisipasi } \\
\text { tindak KSA }\end{array}$ & median & $\begin{array}{c}20 \\
(58 \\
8) \\
14 \\
(41,2)\end{array}$ & 50 & 52,65 & 27 & 64 \\
\hline
\end{tabular}

\section{Sumber: data primer, 2015}

Berdasarkan tabel 7 dijelaskan bahwa skor minimum dari 34 anak terhadap kemampuan dalam antisipasi KSA sebanyak 27 dan maximum 64. Ratarata skor sikap siswa terhadap kemampuan dalam antisipasi tindak KSA sebanyak 50 dengan nilai tengah 52,65. Total anak dengan nilai mean $\mathrm{T}$ skor sebanyak 20 anak 58, $82 \%$ dan < median 14 anak 41, $17 \%$. Artinya sikap positif siswa terhadap kemampuan dalam antisipasi tindak KSA sebnyak 20 anak, sedangkan sikap negatif siswa terhadap kemampuan dalam antisipasi tindak KSA sebanyak 14 anak. Dalam hal ini sikap siswa yang positif lebih banyak dibanding dengan yang negatif.

Hubungan pemanfaatan internet dengan sikap siswa terhadap kemampuan dalam antisipasi tindak KSA dihitung dengan rumus korelasi Spearman Rank menggunakan SPSS 20. Sebelumnya telah di uji normalitasnya dengan menggunakan rumus Shapiro- Wilk didapatkan hasil data tidak normal. Sehingga analisis data yang digunakan adalah analisis non parametrik yaitu Spearman rank.

Hasil perhitungan dapat dilihat pada tabel berikut:

Tabel. 8 Hubungan Pemanfaatan Media Internet dengan Sikap Siswa terhadap Kemampuan dalam antisipasi tindak KSA di PAA AL Falaah Blunyahgede Yogyakarta

\begin{tabular}{lccccc}
\hline \multicolumn{1}{c}{ Variable } & Mean & Med & Min & Max & P \\
\hline $\begin{array}{l}\text { Pemanfaatan } \\
\text { Media Internet }\end{array}$ & 20,20 & 20,50 & 12 & 25 &
\end{tabular}

Sikap siswa terhadap Kemampuan dalam antisipasi tindak KSA

*Uji analisis: Spearman Rank
0,047

$50 \quad 52,65 \quad 27 \quad 64$


Berdasarkan tabel 8, uji korelasi spearman rank dihitung dengan menggunakan SPSS 20, dengan $\mathrm{n}=34,=$ $5 \%$ didapatkan $\mathrm{p}$ value sebesar 0,047 . $\mathrm{P}$ value < 0,05. Maka Ho ditolak, yang artinya terdapat hubungan yang signifikan antara pemanfaatan media internet dengan sikap siswa terhadap kemampuan dalam antisipasi tindak KSA.

\section{B. Pembahasan}

\section{Karakteristik responden di PAA Al- Falaah, Blunyahgede}

Berdasarkan tabel 5 dapat dilihat bahwa usia responden yaitu 10, 11, 12 dan 13 tahun. Pemilihan anak usia ini berdasarkan dari aspek intelektual yang sudah memiliki kemampuan untuk mengamati, melihat hubungan dan memecahkan masalah yang lebih rumit.

Rata-rata pendidikan terakhir orang tua responden dilihat dari tabel 5 berasal dari menengah keatas sehingga berpengaruh dalam pemberian fasilitas internet pada anak. Hal ini diperkuat oleh penelitian Rahayu (2014) bahwa gambaran tingginya penggunaan internet pada anak didukung oleh tingkat pendidikan orang tua yang tinggi.

Oh, Hyun Jung et.al (2013) di Amerika menunjukkan bahwa $80 \%$ dari anak-anak dibawah umur 13 tahun yang memiliki akun disebuah situs jejaring sosial yang mendapat dukungan dalam penggunaan akun mereka: 35\% dari ayah, $33 \%$ dari ibu, 30\% dari teman dan 17\% dari saudara. Pengguna

\section{Pemanfaatan Media Internet di PAA AL Falaah Blunyahgede Yogykarta}

Berdasarkan tabel 6 dijelaskan bahwa pemanfaatan internet oleh siswa PAA AL Falaah Blunyahgede usia 10-13 tahun tinggi. Hal ini dibuktikan dengan. Total anak yang memiliki nilai median sebanyak 19 anak 55,88\% sedangkan < median 15 anak 44,11\%. Artinya pemanfaatan media internet oleh anakanak PAA Al-falaah tinggi.

Ningsih (2012) mengatakan situs jejaring sosial dibawah umur bisa menimbulkan masalah yang sebenarnya jejaring sosial tersebut untuk remaja atau orang dewasa seperti facebook. Usia minimum untuk keanggotaan facebook adalah 13 tahun. Padahal banyak anak dibawah umur memiliki facebook. Hal ini sebagai teguran untuk menyelidiki kemampuan anak bernegosiasi dengan situs yang aman dan menguntungkan.

Sikap siswa terhadap kemampuan dalam antisipasi tindak KSA di PAA AL Falaah Blunyahgede Yogyakarta

Berdasarkan tabel 7 dapat dijelaskan bahwa dari 34 anak T skor kuesioner sikap siswa terhadap. Skor anak yang lebih besar dari rata-rata $T$ skor sebanyak 20 anak dan yang lebih kecil dari rata-rata $\mathrm{T}$ skor sebanyak 14 anak. Hal ini menunjukkan bahwa sikap siswa PAA Al Falaah terhadap kemampuan dalam antisipasi KSA cenderung positif.

Seperti teori yang disampaikan oleh Syaifudin Azwar (2010) bahwa sikap dibentuk oleh beberapa faktor antara lain : a) Pengalaman pribadi, b) Pengaruh orang lain yang dianggap penting, c) Pengaruh kebudayaan, d) Media massa, e) Lembaga pendidikan dan lembaga agama, dan f) Pengaruh faktor emosional. Berdasarkan faktor-faktor pembentuk sikap, siswa PAA Al Falaah merupakan siswa aktif di lembaga pendidikan dan lembaga agama sehingga siswa memiliki sikap yang cukup baik dan menunjukkan bahwa lembaga agama merupakan hal yang penting dalam pembentukan sikap.

Namun demikian, Ramplein dalam buku Psikologi Perkembangan 2014 mengatakan bahwa sejatinya di antara masa pubertas dan adolsensi usia 10 tahun - 21 tahun terdapat krisis remaja yang disebut "Jugencrise". Krisis Remaja adalah pembelokan dalam perkembangan, suatu kepekaan dan labilitas yang meningkat.

Sukmadinata (2003) faktor emosi yang berkembang akan sesuai dengan impuls emosi yang diterimanya. Perkembangan aspek afektif atau perasaan (emosi) berjalan konstan, kecuali pada masa remaja awal (usia 10-14 tahun) dan remaja tengah (usia 15-16 tahun). Pada masa remaja awal ditandai oleh rasa optimisme dan keceriaan dalam hidupnya, diselingi dengan rasa bingung menghadapi perubahan-perubahan yang terjadi pada dirinya. Tidak semua bentuk 
sikap ditentukan oleh situasi lingkungan dan pengalaman pribadi seseorang.

Berdasarkan teori tersebut dapat disimpulkan bahwa di antara masa pubertas dan adolsensi usia 10 tahun - 21 tahun terdapat krisis remaja. Sikap anak dan remaja akan terbentuk positif apabila faktor-faktor pembentuk sikap dapat dikendalikan dengan baik. Monk et all (2014) peran keluarga, teman sebaya, pendidikan, lembaga agama, media massa harus ditanamkan secara positif terutama pada anak usia 10 tahun - 21 dimana kepekaan dan labilitas yang meningkat.

Hubungan Pemanfaatan Internet dengan Sikap siswa terhadap kemampuan dalam antisipasi tindak KSA

Remaja merupakan masa peralihan dari anak-anak menjadi dewasa. Monk (2014) mengungkapkan bahwa masa remaja adalah masa pengembangan identitas diri sehingga remaja lebih mengeksplorasi diri mereka. Eksplorasi ini tidak terkecuali melalui media seperti internet.

Tim edukom (2006) Internet dianggap bukan lagi menjadi teknologi untuk mempermudah hidup saja, tetapi sudah berganti menjadi gaya hidup bagi remaja. Internet telah memberikan pengaruh yang besar bagi perkembangan komunikasi, sosialisasi, informasi dan pembelajaran bagi remaja sehingga internet tidak hanya membawa dampak positif bagi remaja, tetapi juga dampak negative.

Hasil penelitian menunjukkan bahwa dari 34 anak usia 10 - 13 tahun di PAA Al Falaah Blunyahgede, memiliki kemampuan dalam memanfaatkan internet yang tinggi yang ditunjukkan dengan nilai minimum 12, maximum 25, rata-rata skor sebanyak 20,2 dengan median 20,5.

Sikap terhadap kemampuan dalam antisipasi tindak kekerasan seksual menunjukkan hasil yang cukup baik. Analisis bivariabel uji korelasi spearman rank dihitung dengan menggunakan SPSS 20 , dengan $\mathrm{n}=34,=5 \%$ didapatkan $\mathrm{p}$ value sebanyak 0,047. $P$ value $<0,05$. Maka Ho ditolak, yang artinya terdapat hubungan yang signifikan antara pemanfaatan media internet dengan sikap siswa terhadap kemampuan dalam antisipasi tindak KSA.

Hal ini diperkuat oleh teori Syaifudin Azwar (2013) bahwa media massa memiliki kaitan yang erat dalam pembentukkan sikap. Seiring berkembangnya teknologi, internet memainkan peran yang sangat penting bagi penggunanya termasuk anak dan remaja. Media massa membawa pesanpesan yang berisi sugesti yang dapat mengarahkan opini seseorang. Adanya informasi baru mengenai sesuatu hal memberikan landasan kognitif baru bagi terbentuknya sikap terhadap hal tersebut. Azwar (2010) pesan-pesan sugestif yang dibawa oleh informasi tersebut apabila cukup kuat, akan memberi dasar afektif dalam menilai sesuatu hal sehingga terbentuklah arah sikap tertentu.

Komnas perlindungan anak (2013) menyampaikan penyebab terjadinya kasus KSA yaitu $8 \%$ karena pengaruh media pornografi, $17 \%$ terangsang dengan korban, 29\% karena hasrat yang tersalurkan. Dalam hal ini internet merupakan salah satu penyebab kasus kekerasan seksual anak.

Seperti yang dikatakan oleh Sukmadinata (2003) bahwa aspek perkembangan moral dan keagamaan berkembang sejak kecil. Peranan lingkungan terutama keluarga sangat dominan bagi perkembangan aspek ini. Pada mulanya anak melakukan perbuatan bermoral atau keagamaan karena meniru, kemudian berkembang karena control dari dalam dirinya sendiri. Dalam hal ini berarti faktor lingkungan keluarga turut menyumbang peran yang sangat penting dalam memunculkan kemampuan antisipasi tindak KSA.

Selain itu, tidak selamanya internet menberikan dampak yang negatif pada penggunanya. Seperti yang di ungkapkan Rudianto (2010) internet memiliki dampak positif yaitu : (a) Sebagai media pendidikan, seperti materi pembelajaran bisa disampaikan dalam bentuk gambar, suara dan konten-konten interaktif, (b) Media pertukaran data dengan cepat, seperti melalui email, newsgroup, dan wWw (world wide web) (c) Hiburan misalnya bermain game, dan 
mendengarkan music, (d) Media Komunitas, internet membentuk masyarakat baru yang beranggotakan para pengguna internet dari seluruh dunia, dalam komunitas ini pengguna internet dapat berkomunikasi, mencari informasi, berbelanja, dan melakukan aktivitas bisnis, dan (e) Search, media untuk mencari informasi atau data dari seluruh dunia.

Azwar (2010) internet tidak selamanya memberikan dampak negatif. Internet memberikan beberapa dampak positif bagi penggunanya di tambah pendidikan keagamaan juga turut menyumbang peran dalam pembentukan sikap pada siswa PAA Al Falaah. Oleh karena itu dapat disimpulkan bahwa terdapat hubungan yang signifikan antara pemanfaatan media internet dan sikap siswa terhadap kemampuan dalam antisipasi tindak KSA karena media massa merupakan hal yang penting dalam pembentukan sikap. Namun keeratan hubungan dinilai sedang karena ada faktor lain seperti, pendidikan keagamaan yang baik, peran orang tua dan pendidikan orang tua yang cukup tinggi pada siswa PAA Al Falaah turut berperan pula dalam pembentukan sikap terhadap kemampuan dalam antisipasi tindak KSA.

\section{PENUTUP}

\section{A. Simpulan}

Terdapat hubungan pemanfaatan media internet dengan sikap siswa terhadap kemampuan dalam antisipasi tindak kekerasan seksual anak dibuktikan dengan hasil uji korelasi Spearman Rank p value 0.047 dan $\rho \quad 0,344$ artinya ada hubungan yang signifikan.

\section{B. Saran}

Bagi Siswa Sekolah Dasar terutama remaja awal, perlunya meningkatkan sikap antisipasi terhadap tindak KSA pada saat memanfaatkan internet dengan cara memberikan pendidikan dan pengarahan. Bagi Institusi Pendidikan kebidanan perlunya pelatihan atau pendidikan dalam pemberian penyuluhan kesehatan reproduksi pada anak dan remaja khususnya usia $10-13$.

\section{DAFTAR PUSTAKA}

Azwar. S. (2010). Sikap Manusia, Teori dan Pengukurannya. Yogyakarta: Pustaka Belajar

Badan Pemberdayaan Perempuan dan Masyarakat. (2011). Buku Profil Gender dan Anak 2011. Yogyakarta. Badan Pemberdayaan Perempuan dan masyarakat.

Badan Pemberdayaan Perempuan dan Masyarakat. (2014). Kajian Data Perlindungan Anak dari Kekerasan terhadap Anak 2014. Yogyakarta. Badan Pemberdayaan Perempuan dan masyarakat.

Komisi Nasional Perlindungan Anak. (2011). Database Peningkatan Hak Anak. 2010. Jakarta: Komisi Nasional Perlindungan Anak

Monk, F. J; Knoers, A. M. P; Hadinoto, Siti. R. (2014). Psikologi Perkembangan. Yogyakarta: Gadjah Mada university Press

Ningsih, Nike Putria. (2012). Gambaran Pengetahuan dan Sikap tentang Pelecehan Seksual melalui Internet pada Remaja di tingkat Sekolah Menengah Atas. Depok: Fakultas Ilmu Keperawatan Program Studi Sarjana Universitas Indonesia.

Oh, Hyun Jung; Ozkaya, Elif; LaRose, Robert, (2013). How does online social networking enhance life satisfaction? The relationships among online supportive interaction, affect, perceived social support, sense of community, and life satisfaction. USA. Michigan State University.

Soetjiningsih. (2012). Tumbuh Kembang Anak. Jakarta: EGC

Sukmadinata, Nana Syodiq. (2003). Landasan Psikologi Proses Pendidikan. Bandung: Remaja Rosda

Tim Edukom. (2006). Pengenalan Internet. Jakarta: CV Sinar Cemerlang. 